\title{
Perencanaan Kebutuhan Tenaga Kependidikan Berdasarkan Analisis Beban Kerja di Lingkungan Perguruan Tinggi (Studi pada Program Pascasarjana Universitas Brawijaya )
}

\author{
Agustina Salama ${ }^{1 *}$, Andy Fefta Wijaya ${ }^{2}$, Hermawan $^{3}$ \\ Program Magister Manajemen Pendidikan Tinggi, Fakultas Ilmu Administrasi, Universitas Brawijaya \\ Program Magister Manajemen Pendidikan Tinggi, Fakultas Ilmu Administrasi, Universitas Brawijaya \\ Program Magister Manajemen Pendidikan Tinggi, Fakultas Ilmu Administrasi, Universitas Brawijaya
}

\begin{abstract}
Abstrak
Merencanakan kebutuhan tenaga kependidikan dalam hal ini bukan hanya yang berkaitan dengan kuantitas, akan tetapi juga kualitas dari sumber daya manusia yang dibutuhkan. Sehingga dalam hal ini seharusnya analisis beban kerja memainkan peranan yang penting sebab pengadaan tenaga kependidikan yang tidak didasari oleh analisis yang tepat, akan selalu menimbulkan masalah misalnya pendistribusian tenaga kependidikan yang saat ini masih belum mengacu pada kebutuhan tiap unit kerja yang sebenarnya dalam artian belum didasarkan pada beban kerja yang ada. Sehingga dalam perencanaan kebutuhan tenaga kependidikan di lingkungan unit kerja yang ada di Universitas Brawijaya khususnya pada Program Pascasarjana makaperlu dianalisis beban kerja setiap tenaga kependidikan dan juga menganalisis kebutuhan tenaga kependidikan pada unit layanan yang ada di program pascasarjana.Dalam penelitian ini data yang dikumpulkan berdasarkan Observasi atau pengamatan langsung yang dilakukan dalam mengumpulkan data dimana langsung mengamati aktivitas kegiatan yang dilaksanakan oleh tenaga kependidikan di tiap bagian misalnya mengamati berapa waktu yang dibutuhkan oleh tenaga kependidikan dalam mengerjakan suatu pekerjaan selain itu juga dengan wawancara yang dilakukan dalam hal ini adalah menanyakan langung kepada narasumber ataui nforman yang melaksanakan jabatan tersebut selanjutnya dilakukan dokumentasi dalam hal ini dilaksanakan dengan cara mengumpulkan data-data yang berasal dari catatan-catatan, dokumen-dokumen yang dianggap berkaitan dengan masalah yang di telitibaik berupa daftar tupoksi tiap jabatan ataupun data kepegawaian tiap tenaga kependidikan yang berada di Program Pascasarjana.Dengan adanya hasil perhitungan analisis beban kerja pada Program Pascasarjana maka dapat diketahui jabatan-jabatan mana saja yang mengalami kelebihan beban kerja dan kekurangan beba $n$ kerjanya.
\end{abstract}

Kata kunci:analisis beban kerja, perencanaan kebutuhan, sumber daya manusia

\begin{abstract}
Planning the need of educational staff is not only about quantity but also from human resources quality. Thus work load analysis should play important role, because recuritment of education staff which is not based on correct analysis will procure problems, e.g. the distribution of educational staff was not in accordance with the real needs of each work unit; in means has not based on existing work load. Therefore, the plan on the need of educational staff in workunit of University ofBrawijaya, especially Graduate Program will need to be analysed based on the work load of each staff and and analysed the need of educational staff in the services unit in Graduate Program Office. Data colletion was based on the direct observation on the activities of educational staff in conducting the task. We also interview informants in duty and documentation from related notes, documents, main task records in each position and each staff biography in Graduate Progrm Office. The results of analysis showed the specific position with over work load or less work load.
\end{abstract}

Key words:necessity planning, human resources, work load analysis

\section{PENDAHULUAN}

Dalam penyelenggaraan pendidikan di perguruan tinggi maka dosen dan tenaga kependidikan merupakan unsur komponen yang sangat menentukan dalam keberhasilan penyelenggaraan pendidikan dan juga dalam konteks hubungan input dan proses output dalam perguruan tinggi maka dosen dan tenaga

\section{Alamat Korespondensi Penulis:}

Email : salamaagustina@ymail.com

Alamat : Program Magister Manajemen Pendidikan Tinggi,

Fakultas IImu Administrasi, Universitas Brawijaya , Jl. MT

Haryono 163 Malang kependidikan merupakan sumber daya manusia yang penting peranannya dalam memenuhi standar kompetensi lulusan dan juga mempunyai pengaruh terhadap proses belajar dan kualitas lulusan yang semakin kompetitif sehingga kualitas dari mahasiswa di tentukan oleh kualitas sumber daya manusia yang ada pada perguruan tinggi tersebut. Dosen dan tenaga kependidikan inilah yang merupakan SDM yang ada pada perguruan tinggi dimana perlu di kelola secara profesional sehingga perlu di pahami bahwa sumber daya manusia pada perguruan tinggi memiliki peranan yang penting dalam menghasilkan mutu lulusan 
pada perguruan tinggi secara umum. Sehingga berhasil tidaknya pendidikan dalam memproduksi keluaran yang berkualitas, juga sangat ditentukan oleh faktor manusia sebagai sub sistem yang akan turut mewarnai keberhasilan pendidikan dalam meraih mutu lulusan yang lebih baik, yang diharapkan akan merupakan sumber daya manusia yang dibutuhkan dalam mengisi pembangunan jangka panjang [1].

Upaya untuk mewujudkan tenaga kependidikan yang dapat bekerja secara profesional di butuhkan sumber daya manusia yang memiliki kompetensi dan kinerja tinggi demi kemajuan organisasi sehingga di perlukan upaya sistematis dalam meningkatkan kapasitas tenaga kependidikan agar mampu bekerja optimal dalam memberikan pelayanan terbaik sebab tenaga kependidikan merupakan salah satu aset utama suatu fakultas yang menjadi pelaku aktif dari setiap aktivitas organisasi sehingga kemampuan tenaga kependidikan sebagai sumber daya manusia dalam suatu organisasi sangat penting arti dan keberadaannya bagi peningkatan produktifitas kerja di lingkungan organisasinya. Sehingga dengan adanya tuntutan peningkatan kualitas yang semakin tinggi maka Universitas Brawijaya bertekad meningkatkan kinerjanya secara signifikan, indikator peningkatan kinerja dapat dilihat dari perubahan organisasi tata laksana yang berkembang secara dinamis sesuai dengan perkembangan jumlah dan kualitas sumber daya manusia baik dosen maupun tenaga kependidikan [2].

Program Pascasarjana Universitas Brawijaya (PpsUB) sebagai sebuah unit pelayanan juga perlu untuk melakukan analisis beban kerja. Selain sebagai pelaksanaan ketentuan dari pemerintah, hal tersebut juga akan memberikan banyak manfaat bagi unit pelayanan PPS UB. Melihat kondisi riil, secara struktur PPS UB dikepalai oleh Direktur dengan dibantu oleh Wakil Direktur. Dibawahnya terdapat jajaran Bagian dan Sub Bagian yang terdiri dari Bagian Tata Usaha dan beberapa Sub Bagian yaitu Sub Bagian Akademik dan Kemahasiswaan dan Sub Bagian Keuangan dan Umum. Dibawah Sub Bagian dibagi ke dalam beberapa kelompok urusan yaitu Urusan Akademik, Urusan Keuangan, Urusan Umum dan Beasiswa dan Urusan SIM, Promosi dan Publikasi. Sehingga, jumlah kebutuhan pegawai yang akan digunakan sebagai acuan perencanaan dalam menentukan formasi pegawai didasarkan pada hasil perhitungan beban kerja setiap jabatan yang ada di dalam unit pelayanan PPS UB tersebut.
Selain jumlah kebutuhan yang dibutuhkan, juga diperlukan data mengenai jumlah pegawai yang ada pada saat ini. Maka lebih mudah bagi pihak unit pelayanan PPS UB dalam menentukan perubahan formasi yang paling sesuai dengan kebutuhan unit pelayanan secara lebih rinci. Dalam penataan sistem manajemen sumber daya manusia khususnya tenaga kependidikan yang berada di lingkungan Program Pascasarjana Universitas Brawijaya maka yang perlu dilakukan yaitu melaksanakan analisis beban kerja sebab dengan pelaksanaan analisis beban kerja maka diharapkan terpenuhi tuntutan kebutuhan untuk menciptakan efektivitas dan efesiensi serta profesionalisme sumber daya aparatur yang memadai pada setiap unit kerja sehingga mampu melaksanakan tugas dengan baik, dan juga dengan pelaksanaan analisis beban kerja ini dapat menghasilkan suatu tolak ukur bagi pegawai/unit organisasi dalam melaksanakan kegiatannya, yaitu berupa norma waktu penyelesaian pekerjaan, tingkat efesiensi kerja dan standar beban kerja dan prestasi kerja, menyusun formasi pegawai serta penyempurnaan sistem prosedur kerja dan manajemen lainnya, hasil analisis beban kerja juga dapat dijadikan tolak ukur untuk meningkatkan produktifitas kerja serta langkah-langkah lainnya dalam rangka meningkatkan pembinaan, penyempurnaan dan pendayagunaan aparatur negara baik dari segi kelembagaan, ketata laksanaan maupun kepegawaian (3).

Pelaksanaaan analisis beban kerja yang mengacu kepada Pedoman Perencanaan Kebutuhan Pegawai Berdasarkan Beban Kerja Dalam Rangka Penyusunan Formasi Pegawai Negeri sipil (KepMenPAN Nomor: KEP/75/M.PAN/7/2004) [4]. Diharapkan dapat menjadi bahan pertimbangan dalam merencanakan kebutuhan tenaga kependidikan di lingkungan unit kerja yang ada di Program Pascasarjana Universitas Brawijaya. Dan juga dengan adanya pelaksanaan analisis beban kerja ini maka penerapan pelaksanaan Peraturan Pemerintah Nomor 46 Tahun 2011 Tentang Penilaian Prestasi Kerja Pegawai Negeri Sipil dapat berjalan dengan baik dan khususnya bagi tenaga kependidikan yang berstastus sebagai pegawai negeri sipil dapat dijadikan dasar dalam penilaian prestasi kerja yang berimbas pada kesejahteraan pegawai tersebut atau dijadikan dasar dalam penentuan tingkat dalam remunerasi. Berdasarkan permasalahan tersebut diatas maka pelaksanaan analisis beban kerja dan jumlah kebutuhan tenaga kependidikan yang ada pada setiap unit tersebut sesuai dengan beban kerja yang dibebankan 
sehingga diharapkan dari perhitungan beban kerja ini dapat dijadikan acuan dalam perencanaan akan kebutuhan tenaga kependidikan pada Program Pasca Sarjana.

Berdasarkan uraian latar belakang permasalahan diatas, maka yang akan dicapai pada penelitian ini adalah menganalisis beban kerja setiap tenaga kependidikan yang ada pada unit layanan di Program Pascasarjana Universitas Brawijaya dan menganalisis kebutuhan tenaga kependidikan berdasarkan analisis beban kerja yang terdapat pada setiap unit layananpada Program PascasarjanaUniversitas Brawijaya

\section{METODE PENELITIAN}

Dalam penelitian ini penulis menggunakan pendekatan kualitatif dimana pada dasarnya penelitian kualitatif dilaksanakan dalam keadaan yang alamiah (Natural setting) dan data yang dikumpulkan umumnya bersifat kualitatif oleh karena itu penellitian ini disebut penelitian kualitatif dan pada pendekatan kualitatif juga menekankan unsur manusia sebagai alat instrument penelitian, dengan menekankan unsur manusia sebagai alat instrumen maka akan mempermudahpenyesuaian-penyesuaian dengan fakta dilapangan. sehingga dalam pengumpulan data pada penelitian ini maka langkah-langkah yang digunakan yaitu pertama dengan mengadakan observasi di lapangan dengan mengadakan pengamatan terhadap obyek yang akan diteliti dimana mangamati jam kerja efektif yang digunakan dalam menyelesaikan suatu pekerjaan yang dilakukan oleh tenaga kependidikan di bagian unit layanan yang ada di Program Pascasarjana dan juga mengamati standar kemampuan rata-rata tenaga kependidikan yang ada di Program pasca sarjana dalam menyelesaikan suatu tugas selain itu juga mengamati volume kerja setiap jabatan dengan mengamati apakah setiap jabatan mempunyai volume kerja yang sesuai dengan beban kerja jabatan tersebut sebab aspekaspek ini yang akan digunakan sebagai dasar dalam mengadakan perhitungan beban kerja setiap tenaga kependidikan yang berada di tiap unit layanan pada Program Pascasarjana selanjutnya setelah mengadakan pengamatan maka langkah selanjutnya yaitu mengadakan wawancara langsung terhadap responden yang ada di tiap unit layanan pada Program Pascasarjana dimana menanyakan langsung mengenai volume kerja dan beban kerja serta waktu kerja efektif yang digunakan dalam menyelesaikan suatu tugas.

\section{HASIL DAN PEMBAHASAN \\ Perhitungan Beban Kerja Unit Pelayanan Program Pasca Sarjana Universitas Brawijaya}

Program Pascasarjana Universitas Brawijaya adalah program yang khusus mengelola program studi interdisipliner selain itu Program Pascasarjana juga sebagai pengelola penerima beasiswa baik beasiswa dalam negeri maupun beasiswa luar negeri bagi mahasiswa pascasarjana se Universitas Brawijaya dan juga sebagai pelaksana deteksi plagiasi hasil karya ilmiah mahasiswa pascasarjana se Universitas Brawijaya, sehingga dalam rangka penyelenggaraan pelayanan yang efektif dan efisisen pada Program Pascasarjana Universitas Brawijaya maka tenaga kependidikan yang ada pada unit pelayanan pada Program Pascasarjana dituntut untuk profesionalisme artinya mempunyai kompetensi sesuai dengan jabatan yang didudukinya sehingga dibutuhkan penempatan pegawai yang mengacu pada kebutuhan organisasi sebenarnya yang didasarkan pada analisis beban kerja.

Dalam rangka perhitungan beban kerja unit layanan pada Program Pascasarjana maka data jumlah tenaga kependidikan yang ada pada Program Pascasarjana adalah sejumlah 30 orang tenaga kependidikan sedangkan jumlah mahasiswa yang dilayani pada Program Pascasarjana secara keseluruhan dari Program magister dan program doktor berjumlah 500 orang mahasiswa jumlah ini belum termasuk mahasiswa yang dilayani dari penerima program beasiswa pascasarjana se Universitas Brawijaya dan juga jumlah mahasiswa yang dilayani pada pelayanan deteksi plagiasi se Universitas Brawijaya. Sedangkan perlu diketahui bahwa jumlah tenaga kependidikan yang ideal untuk perguruan tinggi pada era teknologi informasi sekarang ini dinilai cukup dengan rasio mahasiswa/administrator $=100$ yang artinya satu tenaga administrasi melayani seratus mahasiswa jika dibandingkan dengan tenaga administrasi yang ada pada Program Pascasarjana berjumlah 30 orang tenaga kependidikan/administrasi dengan melayani mahasiswa program pascasarjana yang berjumlah 500 orang mahasiswa belum termasuk mahasiswa penerima program beasiswa pascasarjana dan juga mahasiswa pada pelayanan deteksi plagiasi se Universitas Brawijaya sehingga jika dilihat dari beban tugas yang diamanahkan ke Program Pascasarjana maka diperlukan analisis beban kerja yang bertujuan adalah untuk menentukan berapa jumlah pegawai yang di perlukan untuk menyelesaikan suatu pekerjaan demikian juga dengan beban kerja yang di bebankan kepada pegawai tersebut 
sebagai sebuah unit pelayanan maka Program Pascasarjana Universitas Brawijaya juga melakukan analisis beban kerja sebagai bentuk manajemen kepegawaian dalam rangka menciptakan kinerja pelayanan prima. Adapun informasi yang dibutuhkan dalam dalam pelaksanaan analisis beban kerja adalah sebagai berikut :

1. Rincian / uraian tugas jabatan.

2. Satuan hasil kerja.

3. Jumlah waktu yang dibutuhkan setiap tugas.

4. Target waktu kerja dalam satuan waktu.

5. Volume kerja merupakan perkalian beban kerja dengan norma waktu.

6. Waktu kerja efektif

Pada pelaksanaan analisis beban kerja maka hal pertama yang dilakukan yaitu dengan melakukan identifikasi uraian tugas yang harus diselesaikan dalam periode waktu tertentu dalam keadaan normal. Artinya, akan diketahui berapa banyak tugas atau kegiatan yang harus diselesaikan dalam waktu tertentu oleh para pemegang jabatan. Perhitungan beban kerja sendiri melalui perhitungan jumlah dan volume pada setiap uraian tugas atau kegiatan sehingga beban/bobot beban kerja didapatkan berdasarkan hasil kali volume kerja dengan norma waktu sehingga analisis beban kerja dilakukan dengan membandingkan bobot/beban kerja dengan norma waktu dan volume kerja. Berdasarkan hasil penelitian, maka data jumlah beban kerja pada masing-masing jabatan yang ada di unit pelayanan Program Pascasarjana Universitas Brawijaya disajikan sebagai berikut padaTabel 1 :

Tabel 1.Jumlah Beban Kerja Jabatan di Unit Pelayanan Program PascaSarjana Universitas Brawijaya

\begin{tabular}{llr}
\hline No & \multicolumn{1}{c}{ Nama Jabatan } & $\begin{array}{c}\text { Jumlah Beban Kerja } \\
\text { Jabatan }\end{array}$ \\
\hline 1 & Direktur & 107.280 \\
\hline 2 & Sekretaris Direktur & 35760 \\
\hline 3 & $\begin{array}{l}\text { Kasubbag Akademik } \\
\text { dan Kemahasiswaan }\end{array}$ & 71.280 \\
\hline 4 & Staf Bagian & 368.810 \\
& Akademik PDKLP & 6.120 \\
\hline 5 & Staf Bagian & \\
& Akademik & 6.120 \\
& PMPANAS & 44.145 \\
\hline 6 & Staf Bagian & 103.320 \\
\hline 7 & Akademik PMPSDA & Staf Bagian \\
& Akademik PMKP & \\
\hline 8 & Staf Bagian & \\
\hline & &
\end{tabular}

\begin{tabular}{|c|c|c|}
\hline & $\begin{array}{l}\text { Akademik bagian } \\
\text { Pendaftaran }\end{array}$ & \\
\hline 9 & $\begin{array}{l}\text { Staf Bagian } \\
\text { Akademik bagian } \\
\text { Presensi dan kelas }\end{array}$ & 5.337 \\
\hline 10 & $\begin{array}{l}\text { Staf Bagian } \\
\text { Akademik }\end{array}$ & 159.720 \\
\hline 11 & $\begin{array}{l}\text { Kepala urusan } \\
\text { SIM,Promosi } \\
\text { danPublikasi }\end{array}$ & 88.940 \\
\hline 12 & $\begin{array}{l}\text { Staf pelaksana SIM } \\
\text { dan Promosi }\end{array}$ & 134.460 \\
\hline 13 & Staf Publikasi Jurnal & 248.850 \\
\hline 14 & Staf Publikasi Jurnal & 18.844 \\
\hline 15 & Staf Publikasi Jurnal & 298.134 \\
\hline 16 & $\begin{array}{l}\text { Kasubbag Umum } \\
\text { dan Keuangan }\end{array}$ & 225.840 \\
\hline 17 & $\begin{array}{l}\text { Kepala Urusan } \\
\text { Keuangan } \\
\end{array}$ & 67.740 \\
\hline 18 & $\begin{array}{l}\text { Bendahara } \\
\text { Penerimaan }\end{array}$ & 18.390 \\
\hline 19 & $\begin{array}{l}\text { Bendahara } \\
\text { Pengeluaran }\end{array}$ & 17.145 \\
\hline 20 & $\begin{array}{l}\text { Staf Bagian } \\
\text { Keuangan }\end{array}$ & 102.350 \\
\hline 21 & $\begin{array}{l}\text { Kepala Urusan } \\
\text { Umum dan } \\
\text { Beasiswa }\end{array}$ & 91.770 \\
\hline 22 & $\begin{array}{l}\text { Staf Bagian Umum } \\
\text { (Pengadministrasian } \\
\text { Umum) }\end{array}$ & 18.620 \\
\hline 23 & $\begin{array}{l}\text { Staf Bagian Umum } \\
\text { (Pengadministrasian } \\
\text { Umum) }\end{array}$ & 20.880 \\
\hline 24 & $\begin{array}{l}\text { Staf Bagian } \\
\text { Beasiswa }\end{array}$ & 21.335 \\
\hline 25 & $\begin{array}{l}\text { Staf Bagian Umum } \\
\text { (Taman ) }\end{array}$ & 46.680 \\
\hline 26 & $\begin{array}{l}\text { Staf Bagian Umum } \\
\text { (supir) }\end{array}$ & 46.800 \\
\hline 27 & $\begin{array}{l}\text { Staf Bagian Umum } \\
\text { (Taman ) }\end{array}$ & 46.680 \\
\hline 28 & $\begin{array}{l}\text { Staf Bagian Umum } \\
\text { (penjaga gedung) }\end{array}$ & 1.391 \\
\hline 29 & $\begin{array}{l}\text { Staf Bagian Umum } \\
\text { (penjaga gedung) }\end{array}$ & 1.391 \\
\hline \multirow[t]{2}{*}{30} & $\begin{array}{l}\text { Staf Bagian } \\
\text { Beasiswa }\end{array}$ & 22.470 \\
\hline & Jumlah & 2122572 \\
\hline
\end{tabular}

Sumber: Data primer diolah, 2015

Berdasarkan Tabel 1 maka dapat disimpulkan perolehan jumlah beban kerja pada setiap jabatan di unit pelayanan PPS UB, sejumlah 2122572 seperti yang telah diuraikan sebelumnya bahwa jumlah beban kerja dijadikan salah satu 
aspek penting dalam menentukan jumlah kebutuhan pegawai dengan lebih tepat. Oleh karena itu, tahapan selanjutnya dari analisis beban kerja adalah mengidentifikasi jumlah pegawai yang dibutuhkan berdasarkan jumlah beban kerja dalam jabatan tertentu. Dengan demikian, jumlah pegawai yang sesuai dengan kebutuhan akan dapat mendorong kemajuan organisasi dalam bidang tata kelembagaan dan kepegawaian atau sumberdaya aparatur.

Analisis Beban Kerja Guna mengetahui Kebutuhan Tenaga Kependidikan Pada Unit Pelayanan Program Pasca Sarjana Universitas Brawijaya

Secara umum, kebutuhan pegawai merupakan jumlah pegawai yang dibutuhkan dalam sebuah organisasi publik untuk dapat menyelenggarakan pelayanan dengan berkualitas. Artinya, setiap pegawai memiliki beban kerja yang cukup yaitu tidak kurang maupun berlebihan. Oleh karena itu, perhitungan kebutuhan pegawai bedasarkan beban kerja merupakan dasar bagi perencanaan sumber daya manusia sehingga dalam rangka mewujudkan dan mempertahankan kualitas pelayanan maka sebuah organisasi publik harus memperhatikan jumlah pegawai yang ada dengan beban kerja yang diberikan agar adanya keseimbangan antara beban kerja dan kinerja. Hal tersebut penting untuk diperhatikan karena dengan jumlah beban yang berlebihan dengan jumlah pegawai yang tidak sesuai tidak akan menghasilkan kinerja yang memuaskan. Dan juga sebaliknya, jika beban kerja kurang akan dapat mengurangi nilai efisiensi dari sebuah jabatan. Tentunya hal tersebut akan memberikan kerugian bagi pihak organisasi atau unit pelayanan itu sendiri.

Berdasarkan Tabel 1, maka dapat diketahui jumlah beban kerja yang ditanggung oleh masingmasing jabatan yang ada di unit pelayanan PPS UB. beban kerja yang di bebankan pada tiap jabatan di PPsUB perlu mengkaji ulang Selanjutnya, dengan rumus yang telah ditentukan yaitu dari jumlah beban kerja tersebut dapat ditentukan jumlah pegawai yang dibutuhkan sebagai berikut pada tabel 2.:

Tabel2. Kebutuhan Pegawai Unit Pelayanan Pasca sarjana Universitas Brawijaya

\begin{tabular}{cccccc}
\hline $\mathrm{N}$ & Nama Jabatan & h Beban & & \multicolumn{2}{c}{ Kebutuhan } \\
$\mathrm{0}$ & & labatan & \multicolumn{3}{c}{ Pejabat/Pegawai } \\
\cline { 3 - 6 } & & $\begin{array}{c}\text { Jumla } \\
\mathrm{h}\end{array}$ & $\begin{array}{c}\text { Pembulata } \\
\mathrm{n}\end{array}$ \\
\hline 1 & Direktur & 107.280 & 1,374 & & 1 \\
\hline
\end{tabular}

\begin{tabular}{|c|c|c|c|c|}
\hline 2 & $\begin{array}{l}\text { Sekretaris } \\
\text { Direktur }\end{array}$ & 35.760 & 0,458 & 1 \\
\hline 3 & $\begin{array}{l}\text { Kasubbag } \\
\text { Akademik dan } \\
\text { Kemahasiswaan }\end{array}$ & 71.280 & 0,914 & 1 \\
\hline 4 & $\begin{array}{l}\text { Staf Bagian } \\
\text { Akademik PDKLP }\end{array}$ & 368.810 & 4,721 & 5 \\
\hline 5 & $\begin{array}{l}\text { Staf Bagian } \\
\text { Akademik } \\
\text { PMPANAS }\end{array}$ & 6.120 & 0,078 & 0 \\
\hline 6 & $\begin{array}{l}\text { Staf Bagian } \\
\text { Akademik } \\
\text { PMPSDA }\end{array}$ & 6.120 & 0,078 & 0 \\
\hline 7 & $\begin{array}{l}\text { Staf Bagian } \\
\text { Akademik PMKP }\end{array}$ & 44.145 & 0,566 & 1 \\
\hline 8 & $\begin{array}{l}\text { Staf Bagian } \\
\text { Akademik bagian } \\
\text { Pendaftaran }\end{array}$ & 103.320 & 1.325 & 1 \\
\hline 9 & $\begin{array}{l}\text { Staf Bagian } \\
\text { Akademik bagian } \\
\text { Presensi dan kelas }\end{array}$ & 5.337 & 0,047 & 0 \\
\hline 10 & $\begin{array}{l}\text { Staf Bagian } \\
\text { Akademik }\end{array}$ & 159.720 & 2,048 & 2 \\
\hline 11 & $\begin{array}{l}\text { Kepala urusan } \\
\text { SIM,Promosi } \\
\text { danPublikasi }\end{array}$ & 88.940 & 1,153 & 1 \\
\hline 12 & $\begin{array}{l}\text { Staf pelaksana } \\
\text { SIM dan Promosi }\end{array}$ & 134.460 & 1,724 & 1 \\
\hline 13 & $\begin{array}{l}\text { Staf Publikasi } \\
\text { Jurnal }\end{array}$ & 248.850 & 3,191 & 1 \\
\hline 14 & $\begin{array}{l}\text { Staf Publikasi } \\
\text { Jurnal }\end{array}$ & 18.844 & 1.292 & 1 \\
\hline 15 & $\begin{array}{l}\text { Staf Publikasi } \\
\text { Jurnal }\end{array}$ & 18.134 & 1,754 & 1 \\
\hline 16 & $\begin{array}{l}\text { Kasubbag Umum } \\
\text { dan Keuangan }\end{array}$ & 225.840 & 2,895 & 3 \\
\hline 17 & $\begin{array}{l}\text { Kepala Urusan } \\
\text { Keuangan }\end{array}$ & 67.740 & 0,868 & 1 \\
\hline 18 & $\begin{array}{l}\text { Bendahara } \\
\text { Penerimaan }\end{array}$ & 18.390 & 0,236 & 1 \\
\hline 19 & $\begin{array}{l}\text { Bendahara } \\
\text { Pengeluaran }\end{array}$ & 17.145 & 0,22 & 1 \\
\hline 20 & $\begin{array}{l}\text { Staf Bagian } \\
\text { Keuangan }\end{array}$ & 102.350 & 1,312 & 1 \\
\hline
\end{tabular}




\begin{tabular}{|c|c|c|c|c|}
\hline 21 & $\begin{array}{l}\text { Kepala Urusan } \\
\text { Umum dan } \\
\text { Beasiswa }\end{array}$ & 91.770 & 1,177 & 1 \\
\hline 22 & $\begin{array}{l}\text { Staf Bagian } \\
\text { Umum } \\
\text { (Pengadministrasi } \\
\text { an Umum) }\end{array}$ & 18.620 & 0,239 & 1 \\
\hline 23 & $\begin{array}{l}\text { Staf Bagian } \\
\text { Umum } \\
\text { (Pengadministrasi } \\
\text { an Umum) }\end{array}$ & 20.880 & 0,268 & 1 \\
\hline 24 & $\begin{array}{l}\text { Staf Bagian } \\
\text { Beasiswa }\end{array}$ & 21.335 & 0,274 & 1 \\
\hline 25 & $\begin{array}{l}\text { Staf Bagian } \\
\text { Umum (Taman ) }\end{array}$ & 46.680 & 0,598 & 1 \\
\hline 26 & $\begin{array}{l}\text { Staf Bagian } \\
\text { Umum (supir) }\end{array}$ & 46.800 & 0,611 & 1 \\
\hline 27 & $\begin{array}{l}\text { Staf Bagian } \\
\text { Umum (penjaga } \\
\text { gedung) }\end{array}$ & 1.391 & 0,598 & 1 \\
\hline 28 & $\begin{array}{l}\text { Staf Bagian } \\
\text { Umum (penjaga } \\
\text { gedung) }\end{array}$ & 1.391 & 0,598 & 1 \\
\hline 29 & $\begin{array}{l}\text { Staf Bagian } \\
\text { Umum (penjaga } \\
\text { gedung) }\end{array}$ & 1.391 & 0,598 & 1 \\
\hline 30 & $\begin{array}{l}\text { Staf Bagian } \\
\text { Beasiswa }\end{array}$ & 22.470 & 0,288 & 1 \\
\hline & Jumlah & 2122572 & 30,19 & 34 \\
\hline
\end{tabular}

Perbandingan Pegawai Yang Dibutuhkan Dengan Pegawai Yang Ada di Unit Pelayanan Program Pasca Sarjana Universitas Brawijaya

Perencanaan kebutuhan pegawai pada suatu instansi mutlak dibutuhkan sehingga dalam rangka memenuhi kebutuhan pegawai yang tepat baik jumlah dan waktu, maupun kualitas. Maka melalui penelitian analisis beban kerja yang dilakukan akan dapat memberikan gambaran pegawai yang dibutuhkan baik kuantitatif maupun kualitatif yang dirinci menurut jabatan dan unit kerja.

Berdasarkan uraian beban kerja dan jumlah kebutuhan pegawai yang sebelumnya dimana untuk mengetahui jumlah pegawai disuatu unit kerja maka dilakukan secara sistematis dengan menggunakan analisis beban kerja serta membandingkan kebutuhan pegawai dengan persediaan yang ada sehingga dapat diketahui kebutuhan riil pegawai sehingga diperlukan rekapitulasi analisis beban kerja dari seluruh jabatan yang ada mengenai setiap aspek-aspek yang diperlukan meliputi jumlah beban, jumlah pegawai yang dibutuhkan, jumlah pegawai yang ada dan selisih atau perbandingan. Sehingga tujuan yang ingin diperoleh dari perbandingan jumlah pegawai yang dibutuhkand an yang sudah ada di unit pelayanan PPS UB adalah memastikan penyusunan formasi pegawai mengalami perubahan sesuai dengan perbandingan pegawai yang ada dan pegawai yang dibutuhkan.Dengan membandingkan kondisi pegawai yang ada dengan pegawai yang akan dibutuhkan maka akan dapat mempermudah proses perubahan formasi kepegawaian unit pelayanan PPS UB dengan lebih tepat sehingga penyusunan formasi yang rasional dalam rangka mewujudkan penyelenggaraan pelayanan yang lebih efektif dan efisien. Dalamtabel 3 disajikan data berupa table perbandingan keduanya sehingga perbandingan dapat dilihat secara lebih jelas.

Tabel 3.Perbandingan Pegawai Yang Dibutuhkan Dengan Pegawai Yang Ada di Unit Pelayanan Program PascaSarjana Universitas $B$ rawijaya

\begin{tabular}{|c|c|c|c|c|}
\hline \multirow{2}{*}{ Namajabatan } & \multirow{2}{*}{$\begin{array}{l}\text { Jumlan Bebaan } \\
\text { Keria abatan }\end{array}$} & \multicolumn{2}{|c|}{ Kebutuhan Pejabat|Pegawai } & \multirow{2}{*}{$\begin{array}{c}\text { Jumlan Pejabat/Pegawa } \\
\text { Vangalda }\end{array}$} \\
\hline & & Jumlah & Pembulation & \\
\hline 1 Direthur & 107280 & 1,374 & 1 & 1 \\
\hline 2 Sexretanis Diretcur & 35760 & 0,458 & 1 & 1 \\
\hline 3 Kepala Sich, Bage, Hadelemik cann Kemanhasiswaan & 711280 & 0,914 & 1 & 1 \\
\hline 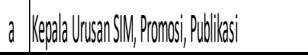 & 88990 & 1,153 & 1 & 1 \\
\hline Staf Pelassans SM Lan Promosi & 13440 & 1,724 & 2 & 1 \\
\hline Stapi Publ|kasilurnal & 24880 & 3,100 & 3 & 3 \\
\hline Staf Bage, Akademik & 268377 & 3,419 & 3 & 3 \\
\hline Staf Bage, Akademik PONL.P & 368810 & 4,721 & 5 & 1 \\
\hline Stafibag, Ardedem'K PMPANAS & 6120 & 0,078 & 1 & 1 \\
\hline StafB Bage, ARademik PMPSDA & 6120 & 0,078 & 1 & 1 \\
\hline Stafbag, Inum & 21000 & 0,669 & 1 & 1 \\
\hline 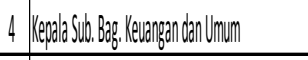 & 215880 & 2,895 & 3 & 1 \\
\hline a Keepala Vusan Kelangenan & 67740 & 0,868 & 1 & 1 \\
\hline Benchatara Pencerimazan & 18930 & 0,366 & 1 & 1 \\
\hline Bendahalar Pengeluaran & 17145 & 0,220 & 1 & 1 \\
\hline Staf Bage, Kelangan & 102350 & 1,312 & 1 & 1 \\
\hline b Keepala Unnsan Umum dan Beasiswa & 91770 & 1,177 & 1 & 1 \\
\hline Staf Bagian Unum & 215995 & 2,69 & 3 & 5 \\
\hline Stafbaganan Alademink & 20110 & 0,559 & 1 & 1 \\
\hline Staf Bag, Adodemik PMP & 444.45 & 0,566 & 1 & 1 \\
\hline Stäbagian Beasiswa & 22170 & 0,288 & 1 & 1 \\
\hline Stabibagian Umum (O'viver) & 46000 & 0,000 & 1 & 1 \\
\hline Total & 2121252 & 27,19 & 34 & 30 \\
\hline
\end{tabular}


Berdasarkan Tabel 3, dapat disimpulkan adanya beberapa kondisi yang belum sesuai dengan kondisi yang dibutuhkan dimana jelas terlihat pada staf bagian pelaksana SIM \& Promosi pada jabatan tersebut jika dilihat dengan beban kerjanya dibutuhkan 2 staf tenaga kependidikan sedangkan pada kenyataannya jabatan tersebut hanya di kerjakan oleh 1 orang tenaga kependidikan, demikian juga pada jabatan staf bagian Akademik PDKLP dimana berdasarkan hasil analisis beban kerja seharusnya jabatan tersebut di laksanakan 5 orang staf tenaga kependidikan tetapi pada kenyataannya jabatan tersebut hanya dikerjakan 1 orang staf tenaga kependidikan hal tersebut juga terjadi pada jabatan Kepala Sub Bagian Keuangan dan Umum dimanaberdasarkan hasil analisis beban kerja pada jabatan tersebut seharusnya dikerjakan 3 orang staf tenaga kependidikan tetapi pada kenyataannya jabatan tersebut hanya di kerjakan oleh 1 orang, dari hasil tersebut diatas maka dibutuhkan pengkajian ulang tentang uraian tugas yang dibebankan pada jabatan yang mempunyai kelebihan beban kerja sehingga staf yang ditugaskan pada jabatan tersebut dapat bekerja lebih efektif dan efisien

Dengan adanya analisis tersebut diatas maka di perlukan pemenuhan kebutuhan dimana hal tersebut memiliki peran penting dalam menentukan tingkat pemenuhan harapan pengguna atau penerima layanan. Oleh karena itu, untuk dapat memenuhi kebutuhan jumlah pegawai yang sesuai diperlukan identifikasi mengenai kondisi pegawai yang ada saat ini. Selanjutnya dapat dilakukan sebuah perbandingan antara kondisi kepegawaian yang ada dengan yang dibutuhkan di unit pelayanan PPS UB. Hal tersebut merupakan langkah penting untuk membantu menentukan keputusan yang akan diambil dalam rangka melakukan perbaikan formasi kepegawaian sehingga sesuai dengan kebutuhan yang sebenarnya

Dengan membandingkan kondisi pegawai yang ada dengan pegawai yang akan dibutuhkan maka akan dapat mempermudah proses perubahan formasi kepegawaian unit pelayanan PPS UB dengan lebih tepat sehingga penyusunan formasi yang rasional dalam rangka mewujudkan penyelenggaraan pelayanan yang lebih efektif dan efisien. Di bawah ini disajikan berupa gambar grafik perbandingan keduanya sehingga perbandingan dapat dilihat secara lebih jelas:
Gambar 1. Perbandingan Pegawai Yang Ada dan Pegawai Yang Dibutuhkan

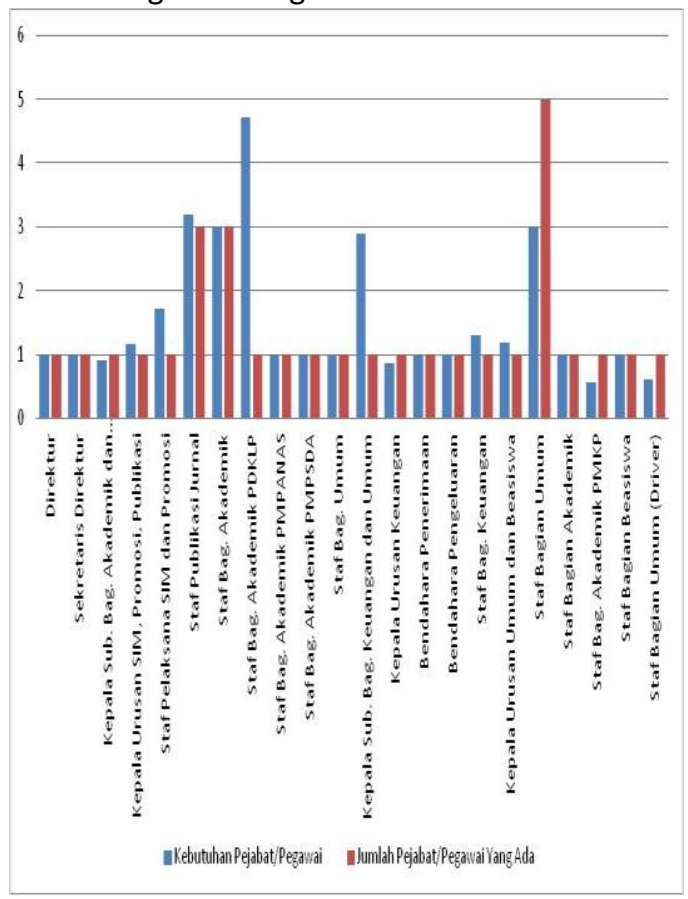

Sumber: Data primer diolah, 2015

Berdasarkan Gambar 1, tentunya adanya perubahan formasi namun perubahan tidak dilakukan secara sembarangan tetapi juga memperhatikan beberapa pertimbangan lainnya, baik bersifat internal maupun eksternal. Perubahan formasi yang dimaksud dalam penelitian ini dibagi menjadi 2 (dua) yaitu pertama perubahan berupa pemindahan pegawai dari jabatan satu ke jabatan lain atau realokasi jabatan karena adanya kelebihan pegawai pada jabatannya. Kedua, perubahan berupa penambahan pegawai baru untuk dapat mengisi posisi kosong yang sesuai dengan kebutuhan.

Pada model perubahan formasi yang pertama, dapat digolongkan pada pola penambahan dan/atau pengurangan pegawai pada jabatan tertentu. Namun, perlu adanya pengaturan khusus dalam melakukan hal tersebut karena penggantian jabatan seorang pegawai tidak hanya dapat didasarkan pada kebutuhan jumlah pegawai pada suatu jabatan tertentu. Tetapi juga harus mempertimbangkan faktor lain yaitu keahlian dan keterampilan yang dimiliki masing-masing pegawai. Setidaknya, pegawai yang dipindah harus memiliki keterampilan dan keahlian linear dengan jabatan baru yang akan dipegang. Sehingga mencegah adanya ketidaksesuaian kompetensi dengan jabatan yang dipegang. Hal tersebut merupakan kajian penting dalam manajemen kepegawaian 
karena juga dapat mempengaruhi baik buruknya kualitas kinerja pegawai.

Sedangkan model perubahan formasi yang kedua, menyediakan susunan pegawai baru sebagai pengisi jabatan kosong yang sedang dibutuhkan oleh jabatan yang memiliki kekurangan jumlah pegawai dan tidak mendapatkan alokasi pemindahan dari kelebihan pegawai. Mengacu pada batasan tersebut, maka sesuai dengan kondisi unit pelayanan PPS UB terdapat beberapa rekomendasi yang dapat diajukan yaitu pertama, realokasi atau pengangkatan jabatan baru perlu dilakukan sebagai berikut:

Tabel 4. Realokasi Jabatan Unit Pelayanan Program Pasca Sarjana Universitas Brawijaya

\begin{tabular}{|c|c|c|}
\hline No & Nama jabatan & Realokasi Jabatan \\
\hline & Direktur & . \\
\hline 2 & Sekretaris Direktur & - \\
\hline 3 & Kepala Sub. Bag, Akademik dan Kemahasiswaan & . \\
\hline a & Kepala Urusan SIM, Promosi, Publikasi & Staf Bagian Akademik dan Kemahasiswaan (Publikasi dan Promosi) \\
\hline & Staf Pelaksana SIM dan Promosi & Staf Bagian Akademik (Jurnal,Plagiasi,Website) \\
\hline & Staf Publikasi Jurnal & - \\
\hline & Staf Bag, Akademik & Staf Bagian Akademik PMKP \\
\hline & Staf Bag. Akademik PDKLP & . \\
\hline & Staf Bag. Akademik PMPANAS & . \\
\hline & Staf Bag. Akademik PMPSDA & - \\
\hline & Staf Bag. Unum & Staf Bagian Akademik \\
\hline 4 h & Kepala Sub. Bag, Keuangan dan Umum & . \\
\hline a & Kepala Urusan Keuangan & - \\
\hline & Bendahara Penerimaan & . \\
\hline & Bendahara Pengeluaran & - \\
\hline & Staf Bag. Keuangan & Pengadministrai Keuangan \\
\hline$b$ h & Kepala Urusan Umum dan Beasiswa & Staf Bagian Akademik dan Kemahasiswaan (Pengadministrasi Keuangan) \\
\hline & Staf Bagian Umum & $\begin{array}{c}1 \text { pegawai realokasi ke jabatan Staf Bagian Akademik dan Kemahasiswaan } \\
\text { (Pegadministrasi Beasiswa) }\end{array}$ \\
\hline & Staf Bagian Akademik & Staf Bagian Umum (Pengadministrasi Umum dan Persuratan) \\
\hline & Staf Bag. Akademik PMKP & Pengadministrasi Beasiswa \\
\hline & Staf Bagian Beasiswa & Pengadministrasi Beasiswa \\
\hline & Staf Bagian Umum (Driver) & . \\
\hline
\end{tabular}

\section{KESIMPULAN}

1. kondisi beban kerja masing-masing jabatan yang ada pada unit layanan pada Program Pascasarjana ditemukan masih belum merata pembagian beban kerjanya dimana terdapat jabatan yang melebihi beban kerjanya yang seharusnya beban kerja tersebut di kerjakan oleh 3 orang tetapi kenyataannya dikerjakan hanya 1orang dan juga ditemukan ada jabatan yang berdasarkan hitungan analisis beban kerja sangat kurang beban kerjanya sehingga total beban kerja unit pelayanan PPSUB sebesar 2229852 OJ. Total beban kerja tesebut diukur berdasarkan jumlah beban pada masing-masing jabatan.

2. Melalui total beban kerja, dilakukan identifikasi mengenai kebutuhan pegawai yang sesuai dengan beban kerja. Hasil yang diperoleh adalah 34 orang, sedang- kan jumlah pegawai yang ada sebanyak 30 orang sehingga terdapat kekurangan staf tenaga kependidikan sebesar 4 orang pada Program Pascasarjana. Dari hasil penelitian tersebut perlu dilakukan perubahan formasi pegawai berdasarkan jabatan dan jumlah pegawai yang dibutuhkan. Perubahan formasi dilakukan dengan 2 bentuk yaitu menyusun realokasi jabatan dan penambahan formasi untuk pegawai baru.

\section{DAFTAR PUSTAKA}

[1] Serdamayanti. 2009. Sumber daya manusia dan produktivitas kerja. Mandar Maju. Bandung

[2] Pola Tata Kelola Universitas Brawijaya BLU. 2008

[3] Peraturan Menteri Dalam Negeri No. 12 Tahun 2008. Pedoman analisis beban kerja di lingkungan departemen dalam negeri dan pemerintah daerah.

[4] Keputusan

Men.PAN No.KEP/75/M.PAN/7/2004.Pedoman perhitungan kebutuhan pega-wai berdasarkan beban kerja dalam rangka penyusunan formasi pegawai negeri sipil.

[5] Moleong, Lexy.2000. Metodologi Penelitian Kualitiatif, Remaja Rosda karya, Bandung

[6] Pasolong, Herbani. 2012, Metode Penelitian Administrasi Publik, Alfabeta, Bandung.

[7] Sulistiyani, Ambar Teguh dan Rosidah 2003, Manajemen Sumber Daya Manusia, Konsep, Teori dan Pengembangan Dalam Konteks Organisasi Publik, Grahallmu.

[8] Wukir, 2013, Manajemensumberdayamanusiadalamorganisa sisekolah, Multi Presindo, Yogyakarta. 